\title{
PENGENAAN PAJAK PENGHASILAN DALAM TRANSAKSI JUAL BELI ONLINE (E-COMMERCE) MENURUT UNDANG-UNDANG NOMOR 36 TAHUN 2008
}

\author{
oleh \\ Adhyt Pratama Febriansyah Asshiddiqie \\ Dewi Rohayati
}

\begin{abstract}
ABSTRAK
Dunia usaha zaman sekarang dapat dilakukan baik secara langsung atau menggunakan media komputer yang saling terhubung yang disebut dengan internet. Hal tersebut ditandai dengan lahirnya penggunaan internet sebagai media perdagangan oleh perusahaan ataupun konsumen dalam melakukan transaksi E-Commerce. E-Commerce diperdagangkan pada suatu website atau sebuah akun sosial. Pengenaan pajak penghasilan terhadap pebisnis online yakni pajak yang dibebankan kepada pelaku jual beli online akan tetapi pelaku jaul beli online ada yang tidak membayar pajak. Ternyata hal ini merugikan pendapatan negara yang bermuara dari sistem perpajakan di Indonesia yang belum dapat menjaring potensi pajak yang ada khususnya jenis usaha jual beli online shop di akun sosial Instagram dan Blackberry Masangger. Sehingga terdapat permasalahan yang terjadi yaitu bagaimana pengenaan pajak penghasilan terhadap jual beli online (transaksi E-Commerce) dan bagaimana kendala-kendala yang dihadapi dalam pengenaan pajak penghasilan terhadap jual beli online (transaksi $E$ Commerce) berdasarkan prinsip Self Assesment menurut Undang-Undang Nomor 36 Tahun 2008 tentang Perubahan Keempat Atas Undang-Undang Nomor 7 Tahun 1983 tentang Pajak Penghasilan. Hasil analisis yang didapat adalah undang-undang yang mengatur khusus mengenai pengenaan pajak penghasilan bagi pelaku usaha jual beli online melalui transaksi E-Commerce belum ada, masih dalam tahap pembuatan teknis dilapangan, sehingga pelaku usaha hendak menggunakan undang-undang pajak penghasilan yang saat ini berlaku, yaitu Undang-Undang Nomor 36 Tahun 2008 tentang Perubahan Keempat Atas UndangUndang Nomor 7 Tahun 1983 tentang Pajak Penghasilan. Kendala-kendala yang dihadapi dalam pengenaan pajak penghasilan terhadap pelaku usaha jual beli online melalui transaksi E-Commerce adalah kurangnya sarana pengawasan kepada petugas terhadap pelaku usaha transaksi E-Commerce. Prinsip self assessment yang menurut undang-undang wajib dipakai dalam menghitung pajak penghasilan justru menjadi hambatan petugas pajak dalam mendeteksi kelemahan pajak penghasilan itu sendiri.
\end{abstract}

Kata kunci: Transaksi E-Commerce, Pajak Penghasilan, Self Assesmen 


\section{PENDAHULUAN}

\section{Latar Belakang}

Dunia usaha di zaman sekarang dapat dilakukan baik secara langsung atau menggunakan media komputer yang saling terhubung yang disebut dengan internet. Karena didukung oleh sebuah jaringan internet sehingga para pelaku bisnis dapat menjual dan menawarkan jasa melalui online.

Meningkatnya penggunaan internet khususnya di Indonesia juga memberikan dampak yang besar bagi dunia bisnis. Jika dahulu, orang-orang berdagang hanya di tingkat lokal di suatu kota, dan ketika hendak mengembangkan usahanya ke luar kota, maka pedagang itu harus memiliki modal yang sangat besar, untuk mengurus berbagai hal, mulai dari perizinan, sewa gedung, upah para pekerjanya. Saat ini jika seorang ingin berdagang atau ingin mempromosikan barang dagangannya sampai ke luar kota, pedagang tersebut cukup membuat akun di sosial media dan menampilkan barang dagangannya di halaman postingannya, konsumen yang ada di luar kota tersebut dapat melihat barang yang ditawarkannya dan jika konsumen tertarik, maka dia dapat melakukan pemesanan barang tersebut cukup hanya dengan beberapa klik pada layar handphone dan ketik nomor kartu kredit pada layar keyboard.

Terkait pajak, seharusnya transaksi perdagangan secara elektronik (E-Commerce) dikenakan pajak sesuai peraturan perundang-undangan yang berlaku, hanya saja saat ini masih mengacu kepada perturan khusus surat edaran Direktorat Jenderal Pajak Nomor SE62/PJ/2013 tentang Penegasan Ketentuan Perpajakan Atas Transaksi E-Commerce. Pelaku usaha yang menawarkan secara elektronik kepada konsumen Indonesia wajib tunduk pada ketentuan perpajakan Indonesia karena dianggap memenuhi kehadiran secara fisik dan melakukan kegiatan usaha secara tetap di Indonesia.

Pengaturan secara khusus mengenai perpajakan atas transaksi E-Commerce ini terdapat dalam surat edaran Direktorat Jenderal Pajak Nomor SE-62/PJ/2013 tentang Penegasan Ketentuan Perpajakan Atas Transaksi E-Commerce. Perkembangan berikutnya, Direktorat Jenderal Pajak mengeluarkan SE-06/PJ/2015 tentang Pemotongan dan atau Pemungutan Pajak Penghasilan Atas Transaksi E-Commerce. ${ }^{1}{ }^{1}$ diharapkan agar bisa menjadi penegasan bahwa ketentuan perpajakan terkait dengan transaksi atas E-Commerce itu sama ketentuannya mulai dari mendaftar, menghitung, membayar, melapor, itu juga berlaku bagi setiap pelaku usaha yang melakukan kegiatan E-Commerce ini.

\section{Identifikasi Masalah}

1. Bagaimana pengenaan pajak penghasilan menurut Undang-Undang Nomor 36 Tahun 2008 tentang Perubahan Keempat Atas Undang-Undang Nomor 7 Tahun 1983 tentang Pajak Penghasilan terhadap jual beli online (transaksi E-Commerce)?

2. Bagaimana kendala-kendala yang dihadapi dalam pengenaan pajak penghasilan terhadap jual beli online (transaksi E-Commerce) berdasarkan prinsip Self Assesment menurut Undang-Undang Nomor 36 Tahun 2008 tentang Perubahan Keempat Atas UndangUndang Nomor 7 Tahun 1983 tentang Pajak Penghasilan?

1) http://ekbis.sindonews.com/read/989943/150/aturan-pajak-bisnis-online-ditarget-rampung-tahun-ini1429149243/, Diakses hari Rabu 20 Desember 2017, pukul 22.31 WIB. 


\section{TINJAUAN PUSTAKA}

Electronic Commerce atau disingkat E-Commerce adalah kegiatan-kegiatan bisnis yang menyangkut konsumen, manufaktur, service provider, dan pedagang perantara dengan menggunakan jaringan-jaringan komputer, yaitu internet E-Commerce sudah meliputi seluruh kegiatan komersial. ${ }^{2}$

Menurut pandangan umum E-Commerce adalah transaksi komersial antara vendor dengan pembeli atau pihak dalam berhubungan kontrak yang sama untuk penyediaan barang dan jasa. Transaksi E-Commerce ini dieksekusi atau dimasukan kedalam media elektronik dimana kehadiran fisik dari para pihak tidak diperlukan, dan media yang ada di jaringan publik atau sistem yang bertentangan dengan jaringan pribadi (sistem tertutup). Jaringan publik atau sistem harus dianggap sebagai sistem terbuka misalnya internet atau World Wide $W e b$. Transaksi ini disimpulkan terlepas dari batas-batas Nasional atau persyaratan lokal.

Pengaturan E-Commerce merupakan amanah Undang-Undang Nomor 7 Tahun 2014 tentang Perdagangan. Pengaturan E-Commerce itu memberikan kepastian dan kesepahaman mengenai apa yang dimaksud dengan Perdagangan Melalui Sistem Elektronik terdapat dalam BAB VIII dan memberikan perlindungan dan kepastian kepada pedagang, penyelenggara Perdagangan Melalui Sistem Elektronik, dan konsumen dalam melakukan kegiatan perdagangan melalui sistem elektronik. "Pengaturan E-Commerce juga bertujuan untuk mempromosikan kegiatan Perdagangan Melalui Sistem Elektronik di dalam negeri,"

Undang-Undang Nomor 7 Tahun 2014 tentang Perdagangan, dalam Pasal 65 butir 1 telah menyebutkan bahwa :

"Setiap pelaku usaha yang memperdagangkan Barang dan atau Jasa dengan menggunakan sistem elektronik wajib menyediakan data dan atau informasi secara lengkap dan benar"

Butir 2 menyebutkan bahwa :

"Setiap pelaku usaha dilarang memperdagangkan Barang dan atau Jasa dengan menggunakan sistem elektronik yang tidak sesuai dengan data dan atau informasi" dan

Butir 3 menyebutkan bahwa :

"penggunaan sistem elektronik tersebut wajib memenuhi ketentuan yang diatur d alam Undang-Undang Nomor 11 Tahun 2008 tentang Informasi dan Transaksi Elektronik (ITE)".

Undang-undang perdagangan sendiri mendefinisikan Perdagangan Melalui Sistem Elektronik sebagai perdagangan yang transaksinya dilakukan melalui serangkaian perangkat dan prosedur elektronik. Jenis pelaku usaha Perdagangan Melalui Sistem Elektronik meliputi pedagang (merchant) dan penyelenggara Perdagangan Secara Elektronik, terdiri atas penyelenggara komunikasi elektronik, iklan elektronik, penawaran elektronik, penyelenggara sistem aplikasi transaksi elektronik, penyelengara jasa dan sistem aplikasi pembayaran dan penyelenggara jasa dan sistem aplikasi pengiriman barang. Bentuk perusahaan Perdagangan Melalui Sistem Elektronik dapat berbentuk orang perseorangan atau berbadan hukum. Penyelenggara Sarana Perdagangan Secara Elektronik dapat berbentuk perorangan atau berbadan hukum.

Pada transaksi elektronik jual beli online melalui internet, menurut Pasal 1 butir 2 Undang-Undang Nomor 11 Tahun 2008 tentang Informasi dan Transaksi Elektronik (ITE) yang dimaksud Transaksi Elektronik adalah perbuatan hukum yang dilakukan dengan menggunakan komputer, jaringan komputer, dan/atau media elektronik lainnya. Para pihak terkait di dalamnya melakukan hubungan hukum melalui suatu bentuk perjanjian atau kontrak

\footnotetext{
${ }^{2)}$ Sutan Remy, Kejahatan \& tindak pidana komputer, Jakarta, PT. Putsaka Utama Grafiti, 2009, hlm. 6.
} 
yang dilakukan secara elektronik dan sesuai dengan Pasal 1 butir 17 Undang-Undang Nomor 11 Tahun 2008 tentang Informasi dan Transaksi Elektronik (ITE) disebut sebagai kontrak elektronik yakni perjanjian yang dimuat dalam dokumen elektronik atau media elektronik lainnya. Pelaku usaha yang menawarkan barang atau jasa secara elektronik wajib menyediakan informasi mengenai syarat-syarat kontrak, produsen dan produk secara lengkap dan benar. Sejalan dengan hal tersebut diketahui bahwa transaksi E-Commerce pada dasarnya merupakan suatu online contract, jadi dalam hal ini transaksi E-Commerce tidak lagi dibatasi oleh batas teritorial hukum suatu negara.

Berkembangnya kegiatan usaha E-Commerce ternyata berhasil menggerakan roda perekonomian sebuah negara. Transaksi-transaksi yang terjadi memang sangat menggiurkan, sehingga menarik minat pebisnis lainnya untuk mendayagunakan internet sebagai jalur pemasaran baru. Internet memungkinkan sebuah perusahaan kecil dan menangah untuk bersaing dengan perusahaan besar lainnya dan meraih peluang di pasar global. Daya tarik lain E-Commerce adalah jangkauan pasar yang tidak lagi terbatas pada sejumlah daerah atau dalam sebuah negara, tetapi seluruh dunia. Ini tentunya yang membuat sebuah perusahaan kecil potensial mendunia sama dengan perusahaan transnasional.

Booming E-Commerce ternyata tidak hanya menarik minat kalangan bisnis, melainkan juga kalangan pemerintah. Ketertarikan kalangan pemerintah ternyata menyadari peran pentingnya e-commerce dalam lingkungan bisnis di era informasi saat ini. Sehingga banyak dari pemerintahan di dunia saat ini yang mendorong pertumbuhan E-Commerce dalam lingkungannya masing-masing. Di sisi lain, pemerintah mulai juga menimbang-nimbang untuk memberlakukan pajak atas E-Commerce guna menutupi defisit anggaran belanjanya.

Memberlakukan pajak internet ternyata tidak semudah yang dibayangkan banyak orang. Berdasarkan survei terungkap menurut data yang diperoleh dari Direktorat Jenderal Pajak ada 1.600 (seribu enam ratus) sampling (pelaku E-Commerce) yang dicoba, dari jumlah itu ada 600 (enam ratus) yang belum teridentifikasikan dan 1.000 (seribu) sudah teridentifikasikan. ${ }^{3)}$ Dari 1.000 (seribu) pelaku usaha baru 620 (enam ratus dua puluh) yang sudah memiliki Nomor Pokok Wajib Pajak (NPWP). ${ }^{4}$ Kendala untuk menerapkan ecommerce adalah waktu untuk merencanakan dan kemudian menerapkannya, pembaruan teknologi, biaya untuk mengimplementasikan dan terbatasnya keahlian teknologi yang dimiliki.

Model usaha berbasis E-Commerce adalah produk dan jasa yang bentuknya dalam format digital seperti social media, umumnya berupa Facebook, Twitter, Instagram, Google, Kaskus, dan Blacberry Messenger. Model ini lebih sulit untuk direka-ulang dari mana tujuannya dan ke mana di sampaikannya barang tersebut. Proses pembelian bisa dilakukan secara online, tapi pengiriman dilakukan secara offline. Artinya, diperlukan cara pembuktian yang lebih dari sekedar cara-cara konvesional yang sudah ada. Akibatnya, produk dan jasa yang format digital tidak hanya rawan penipuan, tapi juga sulit untuk dikenakan jenis pajak apapun.

Transaksi E-Commerce di Indonesia seperti yang telah dijelaskan masih perlu pembenahan dari sisi perundang-undangan agar di kemudian hari tidak terjadi perselisihan dalam menjalankannya. Perpajakan harus menyisipkan masalah pajak untuk transaksi melalui E-Commerce. Kesulitan itu muncul ketika transaksi dilakukan baik yang berupa A dengan B atau B dengan $\mathrm{C}$. Misalnya seperti yang telah dijelaskan hubungan antara penjual dengan pembeli, bagaimana aparat pajak mengawasi telah ada transaksi atau belum antar keduanya melalui E-Commerce tersebut. Begitu transaksi dilakukan, dan transfer dana terjadi, siapa

\footnotetext{
3) Loc. Cit,

4) Ibid.
} 
yang dapat memantaunya, penerapan cyberlaw masih butuh waktu lama, ${ }^{5)}$ karena dari pihak otoritas setidaknya harus mencari cara apapun yang dilakukan di internet tentunya agar dikenai pajak. Mengenai pajak secara tegas diatur dalam Pasal 23 A Undang-Undang Dasar 1945 Amandemen Keempat, yang menyatakan:"Pajak dan pungutan lainnya yang bersifat memaksa untuk kepentingan negara diatur dengan undang-undang”.

Pengertian pajak dan Wajib Pajak Pasal 1 angka (1) Undang-Undang Nomor 28 Tahun 2007 tentang Perubahan Ketiga Atas Undang-Undang Nomor 6 Tahun 1983 tentang Ketentuan Umum Dan Tata Cara Perpajakan, yang menyatakan :

"Pajak adalah kontribusi wajib kepada negara yang terutang oleh orang pribadi atau badan yang bersifat memaksa berdasarkan Undang-Undang, dengan tidak mendapatkan imbalan secara langsung dan digunakan untuk keperluan negara bagi sebesar-besarnya kemakmuran rakyat".

Pajak adalah perikatan yang timbul karena undang-undang yang mewajibkan seseorang yang memenuhi syarat yang ditentukan dalam undang-undang untuk membayar sejumlah tertentu kepada negara yang dapat dipaksakan dengan tiada mendapat imbalan yang secara langsung dapat ditunjuk, yang digunakan untuk membiayai pengeluaran-pengeluaran negara. ${ }^{6)}$

Pajak adalah iuran rakyat kepada kas negara berdasarkan undang-undang yang dapat dipaksakan dengan tidak mendapatkan jasa imbal atau kontraprestasi, yang langsung dapat ditunjukkan dan yang digunakan untuk membayar pengeluaran umum. Dapat dipaksakan artinya bila utang pajak tidak dibayar, utang itu dapat ditagih dengan menggunakan kekerasan, seperti surat paksa dan sita dan juga penyanderaan atau melalui berbagai peraturan pelaksanaan dapat membuka akses selebar-lebarnya guna kepentingan pajak. ${ }^{7)}$

Subjek dan objek pajak secara umum yaitu subjek pajak adalah pihak-pihak yang akan dikenakan pajak, sedangkan objek pajak adalah segala sesuatu yang akan dikenakan pajak. ${ }^{8)}$ Sedangkan jenis pajak adalah pembagian pajak dapat dilakukan berdasarkan sifat, golongan, dan wewenang pemungut. ${ }^{9)}$

Pelaku Usaha wajib melakukan pendaftaran dan memenuhi ketentuan teknis dari instansi yang terkait. Setiap pelaku usaha harus memiliki dan mendeklarasikan etika bisnis. Pelaku usaha dilarang mewajibkan konsumen untuk membayar produk yang dikirim tanpa adanya kesepakatan terlebih dahulu. Informasi atau dokumen elektronik dapat digunakan sebagai suatu alat bukti. Informasi atau dokumen elektronik memiliki nilai kekuatan hukum yang sama dengan akta otentik. Atas transaksi antara pelaku usaha asing dengan konsumen Indonesia dan antara pelaku usaha asing dengan pemerintah Indonesia, berlaku hukum perlindungan Indonesia. Perihal kontrak elektronik, kontrak perdagangan elektronik sah ketika terdapat kesepakatan para pihak. Kontrak perdagangan elektronik paling sedikit harus memuat identitas para pihak, spesifikasi barang dan atau Jasa yang disepakati, legalitas barang dan atau jasa, nilai transaksi perdagangan, persyaratan dan jangka waktu pembayaran, prosedur operasional pengiriman barang dan atau jasa, dan prosedur pengembalian barang dan atau jika terjadi ketidaksesuain. Kontrak perdagangan elektronik dapat menggunakan tanda tangan elektronik dan harus dibuat dalam bahasa Indonesia.

\footnotetext{
${ }^{5)}$ http://ediartikel.blogspot.co.id/2010/03/pajak-untuk-e-commerce.html?m=1, Diakses hari Kamis 25 Januari 2018, pukul 22.30 WIB.

${ }^{6}$ Rochmat Soemitro, Asas Dan Dasar Perpajakan Jilid 1, Bandung, Eresco, 1990 hlm. 51.

7) Erly Suandy, Hukum Pajak, Jakarta, Salemba Empat, 2002, hlm. 66.

${ }^{8}$ Ibid, hlm. 33.

${ }^{9}$ Siti Resmi, Perpajakan Teori dan Kasus, Buku I, Jakarta, Salemba Empat, 2003, hlm. 6.
} 
Terkait dengan transaksi yang dilakukan secara elektronik, maka sudah seharusnya didalamnya terkandung kewajiban pelaku usaha jual beli online untuk membayar pajak penghasilan dari hasil yang mereka terima melalui transaksi E-Commerce.

Pajak penghasilan seperti yang dimuat dalam Pasal 1 Undang-Undang Nomor 7 Tahun 1983 tentang Pajak Penghasilan adalah pajak yang dikenakan terhadap orang pribadi atau perseorangan dan badan berkenaan dengan penghasilan yang diterima atau diperolehnya dalam tahun pajak. Dan dasar hukum pajak penghasilan telah diubah terakhir dengan UndangUndang Nomor 36 tahun 2008 tentang perubahan keempat Undang-Undang Nomor 7 Tahun 1983 tentang Pajak Penghasilan.

Menurut Pasal 21 ayat (1) Undang-Undang Nomor 36 tahun 2008 tentang perubahan keempat Undang-Undang Nomor 7 Tahun 1983 tentang Pajak Penghasilan, yang dimaksud pemotongan pajak atas penghasilan sehubungan dengan pekerjaan, jasa atau kegiatan usaha dengan nama dan dalam bentuk apapun yang diterima atau diperoleh wajib pajak orang pribadi dalam Negeri. Pemotongan pajak penghasilan Pasal 21 ini bagi penerima penghasilan atau pihak yang dipotong pada umumnya merupakan pembayaran pajak dimuka dan dapat dikreditkan atau diperhitngkan dengan pajak terutang pada akhir tahun. Tetapi untuk penghasilan-penghasilan tertentu seperti penghasilan dari jual beli online ini sulit terdeteksi oleh pajak itu sendiri karena pembayarannya melalui sistem transaksi E-Commerce.

\section{PEMBAHASAN}

\section{Pengenaan Pajak Penghasilan Dan Kendala Yang Dihadapi Dalam Pengenaan Pajak Penghasilan Terhadap Jual Beli Online (Transaksi E-Commerce)}

Undang-Undang yang mengatur khusus tentang pengenaan pajak untuk jual beli online melalui transaksi E-Commerce sampai saat ini belum ada atau masih dalam tahap pembuatan teknis dilapangan. Maka dari itu pengenaan pajak terhadap pelaku usaha yang menjual barangnya melalui sistem transaksi E-Commerce masih menggunakan undangundang pajak penghasilan yang saat ini berlaku, yaitu Undang-Undang Nomor 36 Tahun 2008 tentang Perubahan Keempat Atas Undang-Undang Nomor 7 Tahun 1983 tentang Pajak Penghasilan.

Implementasi undang-undang pajak penghasilan terhadap pelaku usaha perihal perangkat hukum seperti tarif, aturan, cara pembayaran sudah cukup, hanya saja tinggal bagaimana pengawasan terhadap pelaku usaha transaksi E-Commerce yang masih kurang ketat. Penghasilan pelaku usaha seperti Bpk. Firmansyah dan Bpk. Rahmad Ekal sudah diatas PTKP (penghasilan tidak kena pajak) atau memasuki standar PKP (penghasilan kena pajak). Aturan minimal dasar tarif PKP yang peratama ada di Pasal 17 seperti yang sudah dijelaskan di BAB II, kedua ada di PP Nomor 46 Tahun 2013 tentang Pajak Penghasilan Atas Penghasilan Dari Usaha Yang Diterima Atau Diperoleh Wajib Pajak Yang Memiliki Peredaran Bruto Tertentu Jo. PP Nomor 23 Tahun 2018 tentang Pajak Penghasilan Atas Penghasilan Dari Usaha Yang Diterima Atau Diperoleh Wajib Pajak Yang Memiliki Perbedaan Bruto Tertentu, yaitu orang yang berpenghasilan dibawah PTKP tidak wajib membayar pajak, sedangkan orang yang berpenghasilan diatas PTKP atau sekitar Rp. 54.000.000.00,- (lima puluh empat juta rupiah) pertahun wajib membayar pajak penghasilan.

Kendala yang dihadapi dalam pengenaan pajak penghasilan terhadap pelaku usaha jual beli online melalui transaksi E-Commerce adalah kurangnya sarana pengawasan terhadap pelaku usaha transaksi E-Commerce, seperti berikut :

1. akses perbankan hanya bisa diakses dengan nilai tukar rupiah tertentu.

2. tidak bisa mendeteksi kegiatan pelaku usaha yang melakukan transaksi E-Commerce melalui bank.

3. jika ingin melakukan kegiatan keuangan harus ijin Menteri keuangan dan gubernur BI. 
4. petugas tidak bisa menghitung PKP pelaku usaha jual beli online melalui transaksi $E$ Commerce karena sekarang sudah berdasarkan prinsip self assessment.

Kendala-kendala itulah yang menghambat petugas pajak dalam mengenakan pajak penghasilan kepada pelaku usaha transaksi E-Commerce, bahkan dalam pembuatan UndangUndang pengenaan pajak penghasilan transaksi E-Commerce masih dalam tahap teknis dilapangan, artinya terdapat banyak kendala dilapangan agar pelaku usaha jual beli online melalui transaksi E-Commerce dapat dikenakan pajak penghasilan.

Prinsip self assessment yang menurut Undang-Undang wajib dipakai dalam menghitung pajak penghasilan justru menjadi hambatan petugas pajak dalam mendeteksi kelemahan pajak penghasilan itu sendiri. Seperti Bpk. Firmansyah dan Bpk. Rahmad Ekal memiliki usaha dan berpenghasilan yang sangat besar perbulan bahkan pertahun, tapi pelaku usaha tersebut tidak membayar pajak dengan alasan tidak tahu dan malas untuk pergi ke kantor pelayanan pajak (KPP), hal ini kurangnya sarana pengawasan petugas pajak untuk terjun langsung ke lapangan, dikarenakan transaksi E-Commerce ini sulit terdeteksi kapan dan dimana pelaku usaha melakukan transaksi tersebut. Dan juga kurangnya kesadaran dan etikad baik dari pelaku usaha untuk memenuhi kewajibannya sebagai wajib pajak dalam membayar pajak penghasilan kepada negara.

Tata cara self assesment hanya dapat berhasil baik bilamana masyarakat pembayar pajak itu sendiri memilki pengetahuan dan disiplin pajak yang tinggi. Menyadari akan kurang tebalnya disiplin perpajakan dari masyarakat terutama pelaku usaha jual beli online melalui transaksi E-Commerce, maka hal ini akan sulit bagi petugas pajak untuk mendeteksi kegiatan transaksi E-Commerce.

\section{PENUTUP}

\section{Kesimpulan}

1. Bahwa sampai saat ini undang-undang yang mengatur khusus mengenai pengenaan pajak penghasilan bagi pelaku usaha jual beli online melalui transaksi E-Commerce belum ada, masih dalam tahap pembuatan teknis di lapangan. Maka dari itu pelaku usaha wajib membayar pajak penghasilan sesuai Pasal 21 dengan menggunakan undang-undang pajak penghasilan yang saat ini berlaku, yaitu Undang-Undang Nomor 36 Tahun 2008 tentang Perubahan Keempat Atas Undang-Undang Nomor 7 Tahun 1983 tentang Pajak Penghasilan.

2. Bahwa inti dari kendala-kendala yang dihadapi dalam pengenaan pajak penghasilan terhadap pelaku usaha jual beli online melalui transaksi E-Commerce adalah kurangnya sarana pengawasan kepada petugas terhadap pelaku usaha transaksi E-Commerce. Prinsip self assessment yang menurut undang-undang wajib dipakai dalam menghitung pajak penghasilan justru menjadi hambatan petugas pajak dalam mendeteksi kelemahan pajak penghasilan itu sendiri. Prinsip self assessment dapat berhasil bilamana masyarakat pembayar pajak itu sendiri memilki pengetahuan dan disiplin pajak yang tinggi. Menyadari akan kurang tebalnya disiplin perpajakan dari masyarakat terutama pelaku usaha jual beli online melalui transaksi E-Commerce, maka hal ini akan sulit bagi petugas pajak untuk mendeteksi kegiatan transaksi E-Commerce.

\section{Saran}

1. Diharapkan pemerintah segera membuat aturan khusus untuk mempermudah Direktorat Jenderal Pajak mengakses transaksi perbankan walaupun syarat dan ketentuan berlaku, dan segera membuat perundang-undangan tentang pengenaan pajak penghasilan transaksi 
E-Commerce agar pelaku usaha dapat membayar pajak penghasilannya sesuai peraturan yang berlaku.

2. Sebaiknya Direktorat Jenderal Pajak lebih gencar mensosialisasikan kepada masyarakat terutama para pelaku usaha jual beli online melalui transaksi E-Commerce agar tingkat kesadaran pelaku usaha menjadi tinggi sehingga pelaku usaha berbondong-bondong mendatangi KPP terdekat, karena pelaku usaha wajib membayar pajak kepada negara.

\section{DAFTAR PUSTAKA}

Erly Suandy, Hukum Pajak, Jakarta, Salemba Empat, 2002

Rochmat Soemitro, Asas Dan Dasar Perpajakan Jilid 1, Bandung, Eresco, 1990

Siti Resmi, Perpajakan Teori dan Kasus, Buku I, Jakarta, Salemba Empat, 2003,

Sutan Remy, Kejahatan \& tindak pidana komputer, Jakarta, PT. Putsaka Utama Grafiti, 2009, http://ekbis.sindonews.com/read/989943/150/aturan-pajak-bisnis-online-ditarget-rampungtahun-ini-1429149243/, Diakses hari Rabu 20 Desember 2017, pukul 22.31 WIB

http://ediartikel.blogspot.co.id/2010/03/pajak-untuk-e-commerce.html?m=1, Diakses hari Kamis 25 Januari 2018, pukul 22.30 WIB.

Sindonews, Aturan pajak bisnis online ditargetkan rampung tahun ini, http://ekbis.sindonews.com/read/989943/150/aturan-pajak-bisnis-online-ditargetkanrampung-tahun-ini-1429149243/, 2015. Diakses hari Rabu 20 Desember 2017, pukul 22.31 WIB.

Undang-Undang Nomor 36 Tahun 2008 tentang Perubahan Keempat Atas Undang-Undang Nomor 7 Tahun 1983 tentang Pajak Penghasila 